\title{
NOTE ON HONEY.
}

By Отто HeHner.

Read at the Meeting, November 11th, 1885.

Since laying before the Society some results of my researehes on honey, and giving directions for its analysis, an eminent firm of sugar refiners, Messrs. A. Lyle and Co., have brought into commerce a product termed artificial honey, which, in all but flavour and aroma, resembles genuine honey most closely, and consisting as it does essentially of dextrose and levulose, as does honey, the methods previously described are not capable of discriminating between it and pure honey. Whilst there is no pretence at the hands of the manufacturers to pass off their article as pure honey, it may 
with certainty be surmised that sooner or later it will be used, by others, fraudulently as substitute for, or admixture with, honey. Analysts may therefore welcome a simple test which allows of its recognition.

On estimating the proportion of phosphoric acid in honeys of undoubted genuineness, I found in four samples the following percentages :-

Light super honey. Light extracted honey. Golden honey. Brown extracted honey. $\cdot 014$ $\cdot 013$ .016 .035

A sample of aphidic, brown honey dew, gave 032 p.c.

Messrs. Lyle's artificial honey did not yield a recognisable trace of phosphoric acid when operating on 50 grammes.

Mixtures, on the other hand, of glucose, made from grain, a honey; such as lately flooded the London market, gave $\cdot 085, \cdot 108$, and $\cdot 107$ per cent. of $\mathrm{P}_{2} \mathrm{O}_{5}$.

It appears, therefore, that pure honey contains from 1 to 3 hundredths of a per cent. of $\mathrm{P}_{2} \mathrm{O}_{5}$, grain glucose, as was to be expected, a much larger quantity, whilst honey made from cane-sugar is devoid of it.

The proportion of $\mathrm{P}_{2} \mathrm{O}_{5}$, and also of total ash, as far as my experience goes, stands in clirect relation to the colour of genuine honey; the lighter it is, the less the quantity of mineral constituents, 50 grms. of light pure honey leaving but an exceedingly slight quantity of ash.

The ash of pure honey, and also of Lyle's artificial preparation, is always strongly alkaline; that from glucose, or glucose mixtures, owing to the mineral acid employed in its manufacture, is always neutral. This fact furnishes a most simple qualitative test for starch-glucose in honey.

For the estimation of such small quantities of phosphoric acid as one has to deal with in honey, I can strongly recommend the method described by me in The ANaLrst, Vol., IV. 1879. For rapidity, simplicity, and accuracy, I believe it to be unsurpassed. 